\title{
Introduction
}

Almost a century ago Theodor Mommsen concluded his study of the legal power of magistrates over Roman foreign policy by emphasizing "die Concentrirung des gesamten Internationalverkehrs bei dem Senat selber." It is safe to say that Mommsen's remains the orthodox scholarly opinion concerning the creation of Roman foreign policy during the middle republic. Standard reference works emphasize that the control of foreign policy usually rested in the hands of the senate. ${ }^{2}$ The same position is taken in many limited studies. And the commu-

\footnotetext{
'Mommsen, Staatsrecht III $2: 1158$.
}

${ }^{2}$ See A. Momigliano in $O C D^{2}$, s.v. "Senatus" ("the conduct of foreign policy [was] usually in the hands of the Senate"); T. Frank in CAH 8: 357-61 ("The Senate in Control"); Kunkel, An Introduction to Roman Legal and Constitutional History, 19 ("The Senate . . held the real leadership of the state firmly in its own hands"); and Jolowicz, Historical Introduction to Roman Law, 40 (quoted in $\mathrm{n} .6$ below).

${ }^{3}$ R. J. Murray, "Cicero and the Gracchi," TAPA 97 (1966): 291, says that the senate was "the main force in the Republic, almost to the exclusion of the assemblies and an independent magistracy"; Crook, Law and Life of Rome, 22, says that the senate enjoyed wide competence, "exercised mainly in . . . the day-to-day running of foreign policy"; and Brisson, "Les mutations de la deuxième guerre punique," 54, speaks of "la concentration de toutes les affaires publiques aux mains du Senat," a concentration exercised especially in foreign relations (55). Carney, "Aims of Roman Military and Foreign Policy," 21-22, sees the period of the Hannibalic War specifically as one in which the senate increased its control over commanders in the field-as a matter of conscious policy. The traditional view of senatorial dominance in, and close control over, Roman foreign relations, reaching its height as a result of the successful conduct of the Hannibalic War, now forms the basis of Hackl's important study of the subsequent development of senatorial-magisterial relations after ca. 150 
nis opinio of scholarship has inevitably found its way into popularizations. ${ }^{4}$ The purpose of this study is to reexamine the hypothesis that the senate was the dynamic force behind the creation of Roman foreign policy in the third and early second centuries B.C. and to place new emphasis on the vital role played in Roman foreign relations by Rome's generals in the field.

A close examination of the ancient evidence reveals that Roman decision making regarding foreign affairs was a complex and cumbersome process, in studying which it is something of a mistake to concentrate on the question of the legal power of the senate as opposed to that of the generals in the field. Certainly the senate possessed the legal, or customary, power-and the patres as a group certainly possessed the informal political power-to determine Roman foreign policy. However, whatever the legal theory, in reality the senate tended to rely heavily on ad hoc decisions already made by Roman commanders in the field (men who were usually the elected magistrates of the Roman people). Indeed, those decisions often formed the basis of Roman foreign policy, especially in regions beyond the shores of Italy.

Our study is organized geographically, moving from northern Italy (chapters I-II) progressively farther afield: to Sicily (chapters III-VI), and then to Spain, Africa, and Greece (chapters VII-IX). We find that the senate exercised greater and more direct control over the situation in the Italian peninsula itself than over regions overseas. In northern Italy, on Rome's Celtic frontier, the senate often formulated definite and specific policies in the first instance (see especially chapter I). The patres also often gave explicit directives to the commanders on the frontier, directives the latter were clearly expected to follow if at all possible, although even in northern Italy there was room for important individual initiative (see especially chapter II). And the amount of room for important individual initiative increased dramatically overseas. There, the decisions of Roman commanders in regard to the es. tablishment or transformation of Roman relations with foreign communities were usually crucial to the fates of those communities (see chapters IV, VI, VII, VIII, and IX). The ad hoc decisions by the men in the field could even include beginning major wars (see chapters III, V, and IX)-although in these cases the generals could also claim to be acting within a broad senatorial consensus concerning the problems in their areas and the means that might be necessary to deal with them.

B.C., Senat und Magistratur in Rom von der Mitte des 2. Jahrhunderts v. Chr. bis zur Diktatur Sullas.

'Cf. K. Richardson, Daggers in the Forum: The Rewolutionary Lives and Violent Deaths of the Gracchus Brothers (London, 1976), 9. 
It is true that legally any decisions made by the generals in the field remained preliminary and transitory until explicitly approved by the senate. ${ }^{5}$ Yet in practice such original decisions on the part of Roman commanders exerted enormous influence over the later creation of policy at Rome. Indeed, as a result of senatorial ratification, most of these magisterial decisions later became official Roman policy. ${ }^{\circ}$ Thus, it would seem that while the extent and manner of senatorial control over and involvement in events differed widely from region to geographical region, in no region were important diplomatic initiatives by the generals completely absent. The possible reasons behind these basic phenomena of Roman decision making in regard to foreign communities will be discussed at the conclusion of this study. But it will not be amiss here to remark that senatorial willingness to defer to decisions already made by Rome's generals in the field appears to have resulted largely from an attitude of mutual trust and mutual confidence within the Roman senatorial aristocracy - to which nearly all the decision makers, in the field and at Rome, belonged.

The core of this study consists of exacting examinations of many specific cases of Roman decision making in regard to foreign communities. Some may object that the method of intense analysis of one particular diplomatic event after another (some of quite minor impor-

${ }^{5}$ Mommsen, Staatsrecht III 2: 1167.

'Contra: Jolowicz, Roman Law, 40: "[O|ne result of this concentration of all international matters in the hands of the senate was that a general in the field, once peace was in sight, directed the ambassadors of the other state straight to the senate in Rome, before which all but preliminary negotiations took place. Also, after an enemy had been so completely conquered that there was no question of a treaty, but only of complete surrender (deditio), it was the senate which sent out commissioners to assist the commander in settling the organization of the conquered territory." On the vital impact of magisterial "preliminary" negotiations with foreign states, however, see the material collected in chapters IV, VI, VII, VIII, and IX below.

'Two previous works have been especially concerned with the importance of individual aristocrats' attitudes and actions for the middle republic; neither, however, has covered the specific topic dealt with in this study, or much of the period involved. Lippold, Consules, has pointed to the great impact at Rome made by the personal characteristics of many of the third-century consuls, but this is mostly with reference to Roman internal politics. Schlag, Regnum in Senatu, concentrates on the alleged triumph hunting of Roman generals in Spain and northern Italy in the decade after the Hannibalic War, as well as on the impact individual Roman politicians had on the development of Roman policies in the Greek East in this same decade. In general, Schlag tends to overemphasize the alleged conflicts between the senate and Rome's generals in the field. 
tance) means that any overall thrust in Roman foreign policy is lost in a mass of detail. I would suggest that this objection begs the question. Was there an overall thrust to Roman policy (especially toward communities overseas) in the third and early second centuries B.c.? Or, more precisely, was there an overt, conscious, and ruthlessly expansionistic thrust, delighting in war, and masterminded by the principes in the Roman senate?

Now, it is certainly true that the Romans of the third and early second centuries, prominently including the members of the senate, preferred to win wars rather than lose them; and they were well aware that various benefits inevitably accompanied victory. But this seems just another way of saying that the Romans of this period were not decadent.' Similarly, the Romans wanted Rome to be strong rather than weak, and, in general, "big" rather than "little." ${ }^{10}$ One aspect of this preference was a desire to surround themselves with as large a system of friendly or subordinate states as possible, and the Romans soon came to identify their own self-interest with the maintenance (and occasionally the expansion) of that system. But there is no need to explain this process in terms of a specially aggressive Roman desire to subjugate and exploit others. ${ }^{11}$ Rome searched fairly continuously to expand its political influence-but so did every other ancient state.

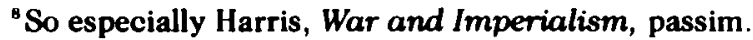

'See the comments of E. N. Luttwak in his review of Harris: AHR 85 (1980): 606. Thus, Harris's very useful collection of evidence concerning Roman attitudes toward war, victory, and the economic gains that naturally resulted from victory (War and Imperialism, 11-104) must still be put in a less shrill context. Note the balanced comments on these matters by Veyne, "Y a-t-il eu un imperialisme romain?" 793-827.

${ }^{10}$ The quinquennial prayer of the Roman censors was for the gods "to make the things of the Roman people better and greater": ut populi Romani res meliores amplioresque facerent (Val. Max. 4.1.10). Harris takes this to be a call for consistent territorial expansion (War and Imperialism, 118-19). But see the comments of Sherwin-White, "Rome the Aggressor?" 177: the censors were concerned with "increase" of all kinds, including demographic and agricultural increase. A phrase similar to the censorial prayer appears in Livy's version of the response of the Delphic oracle to Rome after Cannae (23.11.2), and clearly has merely the implication of safety and well-being; see Gruen, The Coming of Rome I: 282-83. For a non-Roman parallel to the censorial prayer, see $n$. 16 below.

"On the development of such large systems of security originating as a response to direct threats to th: physical integrity of a state, and the later psychological identification of the continuation of such systems indirectly with the ensuring of the physical integrity of that central state, see the general and theoretical discussion by the political scientist G. Liska, Career of Empire (Baltimore, 1978), 11. 
That was Thucydides' famous principle. ${ }^{12}$ Moreover, as Roman strength grew, Rome naturally attracted the attention of weaker states looking for a protector; this, too, was a basic principle of ancient politics. There is never a suggestion that the Romans engineered these requests for help, but it is not surprising that they often answered them positively when they came. Setting aside all other factors (e.g., the search for concrete strategic advantage, the desire for prestige), appeals for help carried with them their own internal dynamic: they required a specific answer, and an outright refusal of aid would obviously hinder the potential protector's efforts to increase its own political influence-or impede the influence of others. (We have seen this dynamic at work often enough in the modern world.) It is therefore surprising how often the Roman senate rejected such appeals for help-or hesitated long before agreeing to them. The Romans did not immediately seize every opportunity for intervention (especially overseas) offered them by small states. ${ }^{13}$ On the contrary: in our period the Romans withdrew their armies from several important regions once the major perceived threat to Rome from these regions had been removed; that is, the patres preferred not to take direct administrative responsibility, even for areas with great economic potential. ${ }^{14}$

Again, there is no doubt that in this period the most important formative experience for senators was a long stretch of military service as young men. Nor can it be denied that the patres were prepared to resort to force in order to achieve vital political objectives. ${ }^{\text {is }}$ As to the latter point, though: of which third-century state can the same not be said? It will not do to divide that harsh world merely into Romans and

12" Of the gods we believe, and of men we know for certain, that by a necessary law of nature they always rule wherever they can": the Athenians at Melos in 416 (Thuc. 5.105.2).

13 On the famous Roman rejection of the appeal of Utica in 238, cf. Polyb. 1.83.5-12. On the hesitant Roman response to the appeal of the Mamertines in 264, see chapter III below. On the very hesitant Roman response to a whole series of appeals from Saguntum, starting in the late 220s, see now A. M. Eckstein, "Rome, Saguntum and the Ebro Treaty," Emerita 52 (1984): 51-68. On the consistent Roman failure to take advantage of the numerous appeals of Greek states against one another after 189, see Gruen, The Coming of Rome II, passim.

${ }^{14}$ On the Roman peace settlement in Africa after the Second Punic War, see chapter VIII below; on the potential wealth of the region, see the comments of Sherwin-White, "Rome the Aggressor?" 179-80. On the factors behind the Roman withdrawal from European Greece after the Second Macedonian War, see chapter IX below. For some of the facts that generally tended to inhibit the Romans from taking on too many responsibilities in the outside world, cf. Sherwin-White, 179.

${ }^{15} \mathrm{Cf}$. Harris, War and Imperialism, 11-53. 
their victims. ${ }^{10}$ And though long military service as young men certainly molded the world-view of senators both as individuals and as a group, that need not mean that the patres ever decided upon war with light hearts. On the contrary: they knew war first hand, and knew it was serious business; it brought glory to individuals and the state, but the patres were well aware that it could also be costly in terms of Roman blood, not least that of their own families. ${ }^{17}$

One should therefore be wary of the expression "Roman imperialism"-at least when it implies something much more ruthless than the imperialism of other ancient states. Rather than a tool of analysis illuminating for us the complex international politics of the third and early second centuries, the expression "Roman imperialism" sometimes comes close to being simply a term of abuse, based on the eventual Roman success in surmounting (via both military and diplomatic skill) every external threat. But the extent of their success in this period came as a surprise even to the Romans themselves. ${ }^{18}$ And this

${ }^{16}$ See the comments of J. Briscoe in his review of Harris: CR 30 (1980): 86-87. On war as the normal condition of relations among the classical Greek states, with peace as the unusual interruption, of. the illuminating comments of J. de Romilly, "Guerre et paix entre cités," 207; also, and somewhat broader in chronological scope, Veyne (cited in $\mathrm{n} .9$ above), 796-801. For the absence of any consensual "society of nations" among the great Hellenistic Greek states, and instead the constant violent clash of interests and ambitions, see especially the comments in Schmitt, "Polybios und das Gleichgewicht der Mächte," 90-102. Note that the primary purpose of victoria in much of Roman thinking was the securing of safety (salus; incolumitas): cf. SherwinWhite, "Rome the Aggressor?" 177. Much is sometimes made of the quinquennial prayer of the Roman censors for "increase" (see $n .10$ above), but in this respect note the fourth-century inscription recording the annual oath of Athenian military recruits: to leave Athens not diminished, but greater and more powerful $(\alpha(\dot{v}) \kappa \dot{\varepsilon} \lambda \dot{\alpha} \tau \tau \omega \pi \alpha \rho \alpha \delta \dot{\omega} \sigma \omega \tau \dot{\eta} \nu \pi \alpha \tau \rho i \delta \alpha, \pi \lambda \varepsilon i \omega \delta \dot{\varepsilon} \kappa \alpha i \dot{\alpha} \rho \varepsilon i \omega)$. On this inscription, see L. Robert, Études épigraphiques et philologiques (Paris, 1938), 302; cf. Stob. 43.48 and Pollux 8.105-6. The similarity here with the Roman prayer is, of course, striking. Presumably if we knew more about the prevailing atmosphere in other ancient communities, the Roman prayer would look even less extraordinary. Indeed, compared to the Athenian ritual, the Roman one was evidently quite mild: what was involved was merely a prayer to the gods (at Athens, the personal oath of all military recruits) once every five years (at Athens, an annual ceremony).

${ }^{17}$ Casualties in the military tribunate-the training ground of future senators-could run quite high during wartime: perhaps two or three out of the twelve military tribunes normally attached to the two consular armies each year. See Harris, War and Imperialism, 40.

${ }^{18}$ That seems evident in the Roman failure for almost half a century to realize the full political implications of the overwhelming military preponderance 
eventual success need not imply the existence of a conscious, insistent, and specific policy (if not, indeed, plan) of imperial expansion on a grand scale.

In fact, what is striking in the Roman historiographical traditions about this period is the lack of any overarching, consciously planned policy. The historiographical traditions of the Romans themselves clearly represented the middle and late third and early second centuries - the "heroic age" of Roman expansion in the Mediterraneanmerely as a period in which the senate and the commanders in the field dealt as best they could with one pressing emergency after another. Thus even the most important Roman decisions concerning foreign relations (e.g., the outbreak of the Hannibalic War) do not appear in Livy's books $21-45$ as the result of cool calculations or long-term, planned policy: rather, everything is ad hoc. The same is obviously true of the mass of comparatively minor Roman decisions regarding foreign communities that Livy also records. Moreover, it seems that Livy was actually more coherent in his presentation of this period than earlier Roman annalists. ${ }^{19}$ And if Livy's is therefore the most coherent account of the third and early second centuries that the Romans were able to come up with, this seems fair evidence that the Romans of the period itself viewed external affairs as a series of ad hoc solutions to discrete problems and suddenly pressing, often confusing, emergencies. ${ }^{20}$ This attitude appears to have been combined with a basic indifference in the senate to the many minor diplomatic decisions about foreign communities inevitably attendant upon the military operations in major wars."

Scholars have been understandably reluctant to accept such a remarkably incoherent presentation of events, often searching instead

they had won in the Mediterranean by 189: the world had changed too fast. On this, see Gruen, The Coming of Rome II, passim. On Roman anxiety in the third and early second centuries, see text immediately below, and also n. 20 .

${ }^{19} \mathrm{Cf}$. the bitter complaints of the historian Sempronius Asellio concerning the character of the sources available to him (ca. 90 B.C.?): Gell. 5.18.9.

${ }^{20}$ On the remarkable lack of Roman analytical thinking, even in the Ciceronian age, concerning their empire (and how they had gained it), see Gruen, The Coming of Rome I: 273-78. With respect to the continuous atmosphere of crisis and emergency at Rome in the third century and early second century, note the ever-increasing number and variety of prodigia reported annually to the senate in this period, and the ever-increasing scale and repetition of religous rites ordered by the patres in response: ef. Wissowa, Religion und Kultus der Römer ${ }^{2}, 60$ and 540-42.

"F. W. Walbank can even speak of a prevailing "mental sloth" in the senate concerning such matters: CR 17 (1967): 90. 


\section{xviii Introduction}

for the organizing strategies or underlying theories behind the day-today decisions that constituted Roman foreign relations. Such scholars-and Polybius was the first-have felt it their duty to make the story of Roman expansion appear more orderly, and hence more understandable to their readers. But it is a besetting vice of intellectuals to overorganize reality by seeing (or creating) order and coherence where none, in fact, may exist. ${ }^{22}$ Historians have another duty to their readers besides the search for (sometimes artificial) synthesis and rationalized causation: namely, to preserve the disorderly specificity of individual events as they follow closely upon one another. ${ }^{23}$

Two futher considerations should strengthen our willingness to allow a certain looseness of organization, a certain emphasis on immediate, ad hoc responses and solutions, and even a certain resultant incoherence to Roman foreign policy in general. ${ }^{24}$ First, there is the prevailing primitiveness of the structure of ancient foreign relations. A most important example is the total lack of permanent embassies and am-

\footnotetext{
${ }^{22}$ Thus, Polybius posited that the Romans consciously began to strive for hegemony over the entire world at a specific point in history. Such a decision, of course, certainly helped explain the situation that had arisen in the Mediterranean by the time of Polybius's maturity in the 150s B.c. Yet the Greek historian apparently could not decide when this signal decision had occurred: at Polyb. 1.3.6, victory in the Hannibalic War is depicted as the essential step in an already-existing Roman plan of universal aggression (cf. also 1.63.9, 9.10, 15.9.2, and 15.10.2), whereas at Polyb. 3.2.6 it is precisely victory in the Hannibalic War that leads to the conception of Rome's plan in the first place. On the contradiction here, of. Walbank, "Polybius and Rome's Eastern Policy," 5, not superseded by the strained attempt of Derow, "Polybius, Rome and the East," $\mathbf{2}-3$, to deny its existence. This knotty problem in Polybian thought tells us much about Polybius conscientiously attempting as a historian to impose some sort of conceptual framework on the expansion of Roman power; but it probably tells us a good deal less about the actual processes involved in Roman expansion. Note that many of Polybius's contemporaries thought that the Romans had gained supremacy because of a chance coming together of various

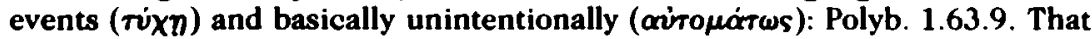
was the view of many Romans as well (see text above).

${ }^{23}$ On the highly contingent character of successful imperial expansions in general, see the comments of A. P. Thornton, Docorines of Imperialism (New York, 1965), 29. Cf. 47-48: "Every doctrine of imperialism devised by men is a consequence of their second thoughts. But empires are not built by men troubled by second thoughts. . . . [Because of the immediate, hard work involved, those concerned] . . . are not inclined to any deep reflection on the ultimate consequences of what they are doing."

${ }^{24}$ Even the term "foreign policy" may itself be begging the question: the concept is modern, and it is not immediately clear how one would express it in Latin.
} 
bassadors - an indication that in the normal course of events ancient central governments, including the Roman senate, did not expect constant official dealings with (or a constant flow of information from) foreign states. ${ }^{25}$ It is no wonder, given this situation, that diplomatic interactions between even major ancient states often took the form of crises verging already on war: often it was only then that communication of complaints and/or political goals to others came to be considered urgent. And yet this was at a point where considerations of state prestige already made negotiation or real compromise extremely difficult. ${ }^{26}$ This primitiveness of the general structure of diplomatic interaction contributed in no small measure to the constant international disorder-a disorder of which the Romans were themselves a part, and perhaps even occasionally victims. ${ }^{27}$

Second, there is the primitiveness of the Roman senate as an institution for decision making in foreign affairs. As A. E. Astin has pointed out, senators did not possess staffs of trained experts, nor was there an independent civil service at Rome to provide the senate as a whole with information about and analysis of international developments. ${ }^{28}$ Furthermore, it is likely that many of the Roman embassies sporadically sent out to deal with or investigate specific problems reported back to the senate only orally. ${ }^{29}$ Thus these reports would not have been available for direct consultation at a later time, if that ever became necessary: in such cases, what counted would have been the recollections of the report (such as they were) among the patres. This could also be true even of the formal presentation to the senate of a commander's acta upon his return to Rome from his assigned provincia. ${ }^{30}$ The situation was further complicated by the fact that, for the

\footnotetext{
${ }^{25}$ On the primitiveness of the structures of ancient "international relations" in general, emphasized by the lack of permanent embassies and ambassadors, cf. Szidat, Caesars Tätigkeit, 1-3. On Rome specifically, ef. especially Astin, "Politics and Policies in the Roman Republic," 14-15.

${ }^{26}$ Obviously, severe diplomatic crisis was not the only form of interaction existing between ancient states and peoples. Embassies could also be sent, or appear, for other specific purposes: to express friendship, or to ask for protection.

${ }^{27}$ For a wonderful story of appalling diplomatic incompetence involving relations between two allegedly sophisticated Hellenistic Greek states (the Achaean League and Ptolemaic Egypt), see Polyb. 22.7-9.

2s"Politics and Policies in the Roman Republic," 15.

" Ibid.

${ }^{\text {so }}$ See, for example, Livy 26.28.1-2 on M. Valerius Laevinus's address to the senate immediately upon his return from Greece and entry into office as consul in 210.
} 
most part, no official records were kept in this period even of the senatorial proceedings themselves. ${ }^{31}$ And the existing diplomatic archives at Rome were in any case both rudimentary and disorganized..$^{32}$

The absence of the supportive machinery essential for the making of coherent, consistent, and centralized foreign policy by the senate was combined with the inherently cumbersome nature of the senate itself. Once more we turn to Astin's analysis: an assembly of some three hundred persons, each with his own politics and political ties, is hardly an ideal instrument for the planning of complicated policies or their steady implementation over time. ${ }^{33}$ On the contrary: it was natural for the patres as a group to delegate authority, natural for them to accept the (legally preliminary) "recommendations" that came back to them ${ }^{34}$

However, I wish to make it clear that in this study I am not suggesting that the senate was a passive institution that, over the course of the seventy years covered here, simply spent its time ratifying the ad hoc decisions of Roman commanders in the field. Such a theory would be as simplistic as the theory that the senate had a master plan of imperial expansion. It is obvious that in many crises the senate took the lead in directing Roman foreign relations. Thus the senate led Rome into war in Illyria in the 230s, and into the second war with Carthage in 218; perhaps most strikingly, the senate in 200 forced a new war with Philip V of Macedon upon an unwilling populus. ${ }^{35}$ Moreover, each

\footnotetext{
${ }^{31}$ For conditions prevailing here before Julius Caesar's reform, cf. Cic. Sull. 42 and Plut. Cat. Min. 23.3; on the reform, see Suet. Jul. 20.1. Official senatus consulta (in other words, the end result of such senatorial proceedings) were recorded, and Cicero could consult a book containing senatus consulta from a hundred years before his own time (Ad Att. 13.33.3). Whether senatus consulta of the past were so easily accessible in the third century and very early second century is unknown, but surely doubtful in an age when books in Latin were still a novel idea at Rome. That left the official archives as a source: see below.

${ }^{32}$ On the deplorable state of the archives (even in the first century), see especially Cary, "A Forgotten Treaty Between Rome and Carthage," 67-68. And note Cicero's complaint about the absence of official copies even of Rome's internal laws; such was not the case in Greek states (De leg. 3.46). Moreover, an authoritative list of Rome's past consuls year by year-surely the most basic of state documents - was probably not available in the second century, and perhaps not even in the first: see T. P. Wiseman, Clio's Cosmetics: Three studies in Greco-Roman Literature (Leicester, Eng., 1979), 13 and n. 30.

su"Politics and Policies in the Roman Republic," 15.

"M Ibid.

${ }^{35}$ For the senate and the First Illyrian War, cf. Polyb. 2.8. On the senate and the outbreak of the Second Punic War, see Astin, "Saguntum and the Origins of the Second Punic War," 593-95. On the patres' forcing war with Philip V. in 200, ef. especially Livy 31.6.1-8.4.
} 
spring the senate established the magisterial and promagisterial provinciae and the forces that were to be allotted to their respective commanders. ${ }^{36}$ This annual decision constituted, in the most fundamental sense, the administration of the empire of the Roman people, and officially established which regions around the Roman horizon might need to feel the full impact of Roman power. There is every reason to believe that the determination of provinciae was taken very seriously indeed ${ }^{37}$ And when foreign envoys did come to Rome on specific missions, they always appeared before the patres; it was the patres who then decided what impact, if any, the words of these envoys would have on the course of Roman action. ${ }^{38}$

Again, the senate could issue specific directives to the generals in the field whenever it wished (although it rarely did so in the overseas commands). Nor is there any doubt that the senate took very seriously its task of ratifying the terms of the "preliminary" treaties or other agreements worked out in the field by Rome's generals: there was nothing pro forma about this (although outright senatorial rejection of such treaties or agreements was rare). ${ }^{39}$

Nevertheless, important as these senatorial functions were, they were far from being the consistent formulation of complex, coherent, and far-sighted foreign policy. Instead we find a piecemeal, disjointed approach to foreign relations-each problem taken as it came. The effect: because of disorderly and improvisatory senatorial government and one pressing foreign crisis after another, the ad hoc decisions of individual Roman generals in this period often played a crucial role in the determination of Roman foreign relations. That the following study concentrates on the political impact of such individual decision making does not mean that I take this phenomenon to be the whole story. It is, however, an important part of the story-and one that has long been ignored.

The Roman republic in the third and early second centuries faced a threatening and disordered international environment. Firmly centralized institutions for formulating consistent foreign policy would probably have been of great advantage to the Romans in dealing with that environment. The Romans did not, however, develop such sophisti-

${ }^{36}$ Cf. Mommsen, Staatsrecht III 2: 1071-80.

${ }^{37}$ See, for example, the debate over the determination of P. Cornelius Scipio's provincia for 205, presented at Livy 28.40.1-45.8.

${ }^{s / 4}$ Cf. Mommsen, Staatsrecht III 2: 1148-55.

.14 For examples of senatorial decisions here, see chapters IV, VI, VIII, and IX below. 


\section{xxii Introduction}

cated institutions or such a highly organized approach to foreign affairs at any time under the republic. That is, there does not seem to have been at Rome any of Mommsen's "Concentrirung des gesamten Internationalverkehrs" in anyone's hands. On the contrary. Not only does much Roman decision making in foreign relations in this period appear ad hoc and improvised, but the institutional structures producing such decisions seem to have been remarkably diffuse and decentralized, even primitive. ${ }^{40}$ In other words, Roman senatorial government, and the Roman people with it, simply "muddled through." 11 These are the themes that will emerge in greater detail below.

${ }^{4}$ Of course, decentralization possessed its own advantages, not least in terms of the flexibility that allowed those men with real knowledge of local conditions (i.e., the Roman commanders on the spot) to have a strong de facto influence over official decisions back in Rome.

"The expression, of course, is British. So, too, the situation: British governors in far-off places appear to have often enjoyed an influence over foreign relations quite comparable to the great influence of Roman generals suggested above. See J. Benyon, Proconsul and Paramountcy in South Africa (Durban, 1980), especially 322-42, with its thesis that the development of British policy in the region often depended on "the exertion of the free will of individuals" on the spot (342). Cf. P. K. Chatterji, The Making of India Policy, 1853-1865 (New Delhi, 1975). 